\title{
Feline diabetes mellitus - the Swedish situation
}

\author{
Malin Öhlund ${ }^{1 *}$, Tove Fall ${ }^{2}$, Bodil Ström Holst ${ }^{1}$, Helene Hansson-Hamlin ${ }^{1}$, Brenda Bonnett ${ }^{3}$, Agneta Egenvall ${ }^{1}$ \\ From Animal Obesity - causes, consequences and comparative aspects \\ Uppsala, Sweden. 14-16 June 2015
}

\section{Introduction}

Diabetes mellitus (DM) is a common endocrinopathy in cats. Feline DM is similar to human type 2 diabetes (T2D), with obesity as a major risk factor in both cats and humans. Genetics play an important role in the development of obesity and T2D in humans.

\section{Objectives}

The aim was to describe the incidence of feline diabetes in Sweden, and the association with different epidemiologic risk factors.

\section{Methods}

We used data from a cohort of 504,688 cats in a Swedish insurance company from 2009 to 2013, contributing with $1,229,699$ cat-years at risk (CYAR). Overall incidence rates (IR) and IRs stratified on age, breed and gender were estimated.

\section{Results}

The IR of diabetes was twelve cases per 10,000 CYAR. Male cats had twice as high IR as females. A significant association with breed was seen, with the Burmese, Russian Blue, Norwegian Forest Cat, and Abyssinian breeds at increased risk. Also domestic cats were at higher risk compared to purebred cats. IRs of DM was highest in cats 12 to 15 years old.

\section{Conclusions}

Our results identified several cat breeds associated with an increased risk of DM. Also male gender and middle age were risk factors for DM. A link has been shown between obesity and DM in cats. A higher incidence of obesity has been reported in domestic cats as compared to purebreds, in male cats, and in middle-aged cats;

\footnotetext{
* Correspondence: malin.ohlund@slu.se

'Department of Clinical Sciences, Swedish University of Agricultural Sciences, Uppsala, Sweden

Full list of author information is available at the end of the article
}

these groups are similar to those in which we identified a higher occurrence of DM.

\section{Authors' details}

${ }^{1}$ Department of Clinical Sciences, Swedish University of Agricultural Sciences, Uppsala, Sweden. ${ }^{2}$ Department of Medical Sciences, Uppsala University, Uppsala, Sweden. ${ }^{3}$ B. Bonnett Consulting, Georgian Bluffs, Ontario, Canada.

Published: 25 September 2015

\section{doi:10.1186/1751-0147-57-S1-013 \\ Cite this article as: Öhlund et al:: Feline diabetes mellitus - the Swedish} situation. Acta Veterinaria Scandinavica 2015 57(Suppl 1):013.

Submit your next manuscript to BioMed Central and take full advantage of:

- Convenient online submission

- Thorough peer review

- No space constraints or color figure charges

- Immediate publication on acceptance

- Inclusion in PubMed, CAS, Scopus and Google Scholar

- Research which is freely available for redistribution

Submit your manuscript at www.biomedcentral.com/submit
() Biomed Central 